\title{
THREE NEW MASDEVALLIA SPECIES (ORCHIDACEAE: PLEUROTHALLIDINAE) FROM PERU
}

\author{
Stig DalströM ${ }^{1,3} \&$ Saul Ruíz Pérez ${ }^{2}$ \\ 12304 Ringling Boulevard, unit 119, Sarasota FL 34237, U.S.A. \\ Lankester Botanical Garden, University of Costa Rica, Cartago, Costa Rica \\ and National Biodiversity Centre, Serbithang, Bhutan \\ ${ }^{2}$ Allamanda 142, Surco, Lima 33, Peru \\ ${ }^{3}$ Corresponding author: stigdalstrom@juno.com
}

\begin{abstract}
AвSTRACt. Three new Masdevallia species are described, illustrated and compared with similar species. A brief taxonomic discussion is held about the justification for describing the new taxa as Masdevallia and not as belonging to any of the recently proposed segregated genera. The first species is most similar to M. rimarimaalba but differs in having a more tubular flower and a narrower lip, the second species is similar to M. dudleyi and $M$. nunezii but differs in the richly pubescent sepals, and the third species is distinguished from other similar and multiflowered Masdevallia species by the rugose lip.
\end{abstract}

Key words: Orchidaceae, Masdevallia, Pleurothallidiinae, Epidendreae, new species, Peru, taxonomy

In the most traditional circumscription, genus Masdevallia Ruíz \& Pav., is a large genus in the Pleurothallidiinae, distributed throughout the New World tropics from Mexico in the north to southern Bolivia, primarily along the Andes, but with a few species occurring in Brazil as well. The systematic classification of Masdevallia has changed considerably over the years, however, and many groups of species have been transferred to new genera, such as, Dracula Luer, Dryadella Luer, Porroglossum Schltr., Scaphosepalum Pfitzer and Trisetella Luer.

These transfers were to a considerable extent based on vegetative features in addition to flower morphology, which is user-friendly and makes the genera relatively easy to identify, even without the presence of flowers. A modern classification of the remaining about 350 species of Masdevallia (Luer 1986) included vegetatively rather similar plants, which made it easy to spot a Masdevallia even without flowers and from several meters distance. Recently, however, molecular work with DNA sequencing has complicated the picture (Abele et al. 2005, Pridgeon $\&$ Chase 2001), which led Luer to propose a division of the genus, by then about 500 species rich, into 16 new genera, in addition to three already described segregates and the original Masdevallia (Luer 2006).

Many growers and scientists have not accepted this proposition and maintain the genus more or less as it was circumscribed by Luer in 1986. For practical reasons, in addition to strict taxonomic reasons, we chose to follow a broader concept of the genus and therefore describe the species treated here as members of Masdevallia sensu Luer 1986, but at this time without placing them in any particular subgenus or section.

Masdevallia hortilankesteriani Dalström \& RuízPérez, $s p$. nov.

TYPE: Peru. Junín. Terrestrial along road ComasCochas, S11 ${ }^{\circ} 41.008^{\prime}, \mathrm{W} 075^{\circ} 04.22^{\prime}, 2800$ m. 13 Nov. 2011, S. Dalström 3510 (holotype, USM). Figs. 1-4.

Diagnosis: Masdevallia hortilankesteriani is similar to the sympatric M. rimarima-alba Luer (Fig. 5.) but differs by a more compact vegetative habit, a more campanulate flower with longer and thicker sepaline tails and a narrower lip.

Geophytic or lithophytic herb. Plant medium in size, caespitose, root-thickness medium for the

\footnotetext{
* This paper was prepared in the framework of the celebration of Lankester Botanical Garden's $40^{\text {th }}$ anniversary.
} 


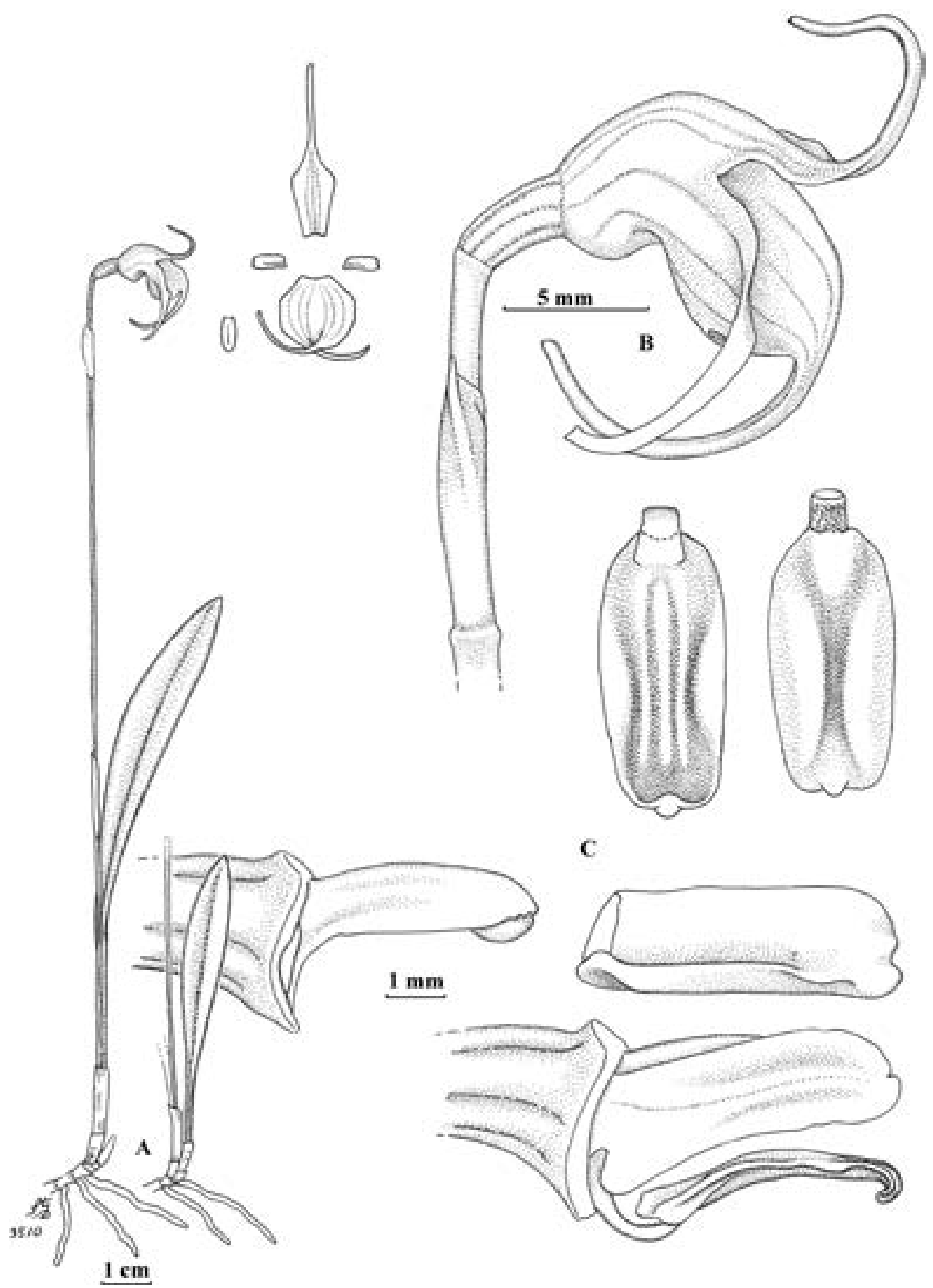

FiguRE 1. Masdevallia hortilankesteriani. A - Plant habit, with a dissected flower. B - Flower lateral view. C - Column, lip and petal views. Drawn from the holotype by Stig Dalström. 


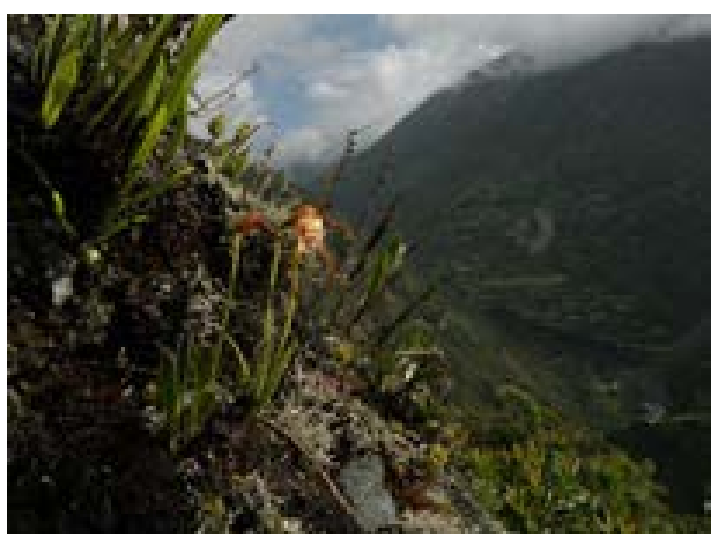

FIGURE 2. Masdevallia hortilankesteriani in natural habitat. Photo by Stig Dalström.

genus. Ramicauls erect, slender, 1.0-2.5 cm long, enclosed basally by 3 to 4 tubular sheaths. Leaf erect, coriaceous, petiolate, blade basally conduplicate and cuneate, elliptic, obtuse to acute, $6-10 \times 0.8-1.1 \mathrm{~cm}$, including the $1.5-3.0 \mathrm{~cm}$ long petiole. Inflorescence erect, terete, single-flowered, with a to $c a .15 \mathrm{~cm}$ long peduncle; peduncular bract 1, tubular, below the middle of the peduncle, $c a \cdot 1.7-1.8 \mathrm{~cm}$ long; floral bract appressed, tubular, ca. $1 \mathrm{~cm}$ long; pedicel ca. 2.0-2.2 cm long; ovary smooth, $c a$. $0.4 \mathrm{~cm}$ long. Flower attractive, campanulate; dorsal sepal white to pale rose, with purple longitudinal stripes along the 3 veins, glabrous and carinate externally, glabrous to microscopically pubescent internally, slightly concave, cuneate, angulate-obovate and connate to the lateral sepals for $c a .13 \mathrm{~mm}$, acuminate into a dorsally rather thick, frontally dull greenish yellow, ventrally purplish tail, $c a .36 \times 10 \mathrm{~mm}$, including the $c a .16-17 \mathrm{~mm}$ long tail; lateral sepals similar in texture and coloration, 3-veined, connate for $c a .13 \mathrm{~mm}$, angulate-ovate, acuminate with apical, rather thick, slightly recurved tails, $c a .30 \times 16 \mathrm{~mm}$, including the $c a .13-15 \mathrm{~mm}$ long tails; petals white, cartilaginous, obliquely oblong and apically truncate and obliquely bilobed, with a ventral fleshy ridge, extending from a lobed, or "toothed", base, continuing along the lower edge and diminishing near the apex, $c a .6 \times 2 \mathrm{~mm}$; lip whitish, heavily flushed with brownish purple, with darker longitudinal ventral stripes and a dark purple-brown apex, hinged on the column foot, with a basal swelling and shallowly notched, cuneate, oblong-elliptic, apically truncate, recurved and bluntly apiculate, dorsally slightly canaliculate between

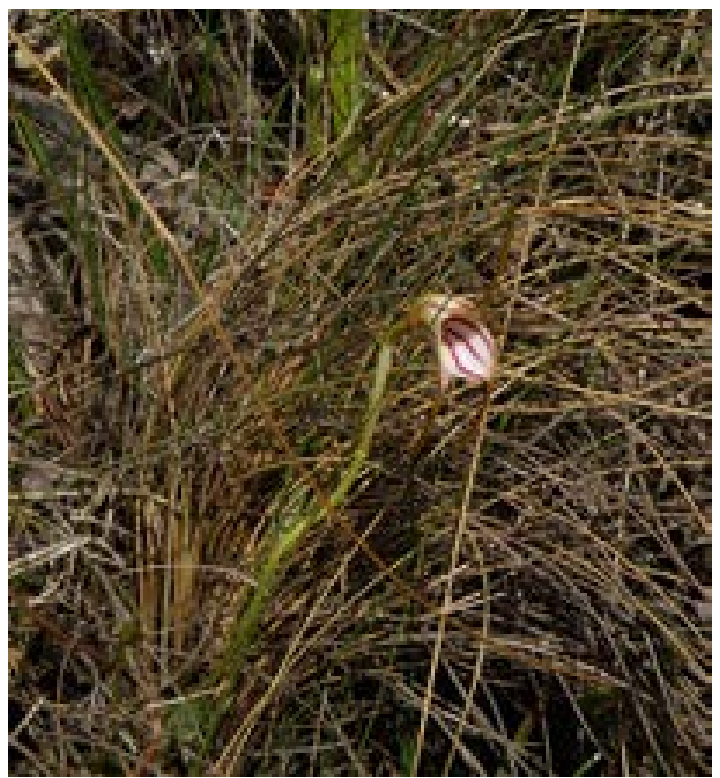

FIGURE 3. Masdevallia hortilankesteriani in natural habitat. Photo by Stig Dalström.

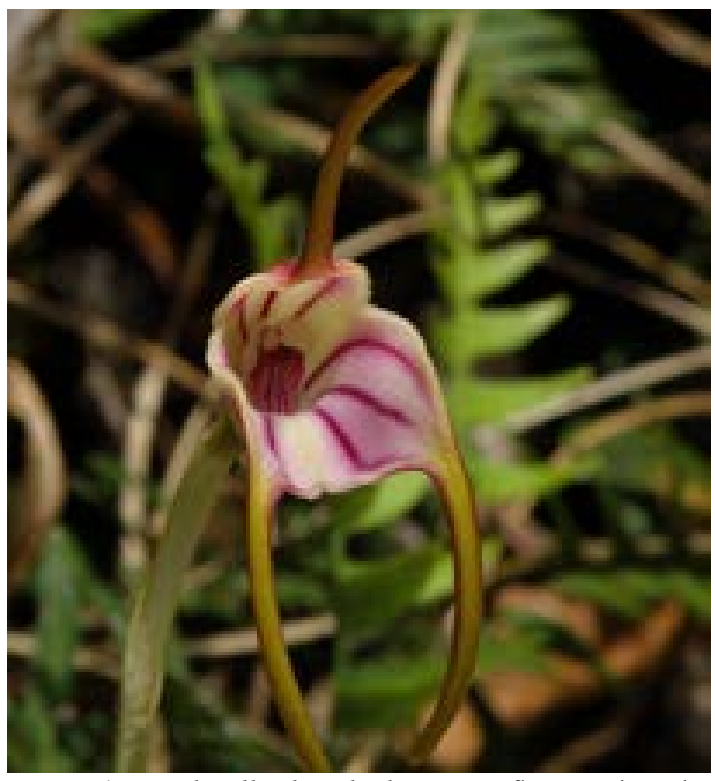

FIgURE 4. Masdevallia hortilankesteriani flower. Photo by Stig Dalström.

low fleshy ridges, $5.0 \times 2.5 \mathrm{~mm}$; column white with brown-purple ventral stripes, semi-terete, straight, $c a$. $4 \mathrm{~mm}$ long, with an equally long, curved foot that is slightly pubescent dorsally near the apex; anther cap white and campanulate; pollinia not seen.

PARATYPes: Peru. Junín. Terrestrial along road Comas- 


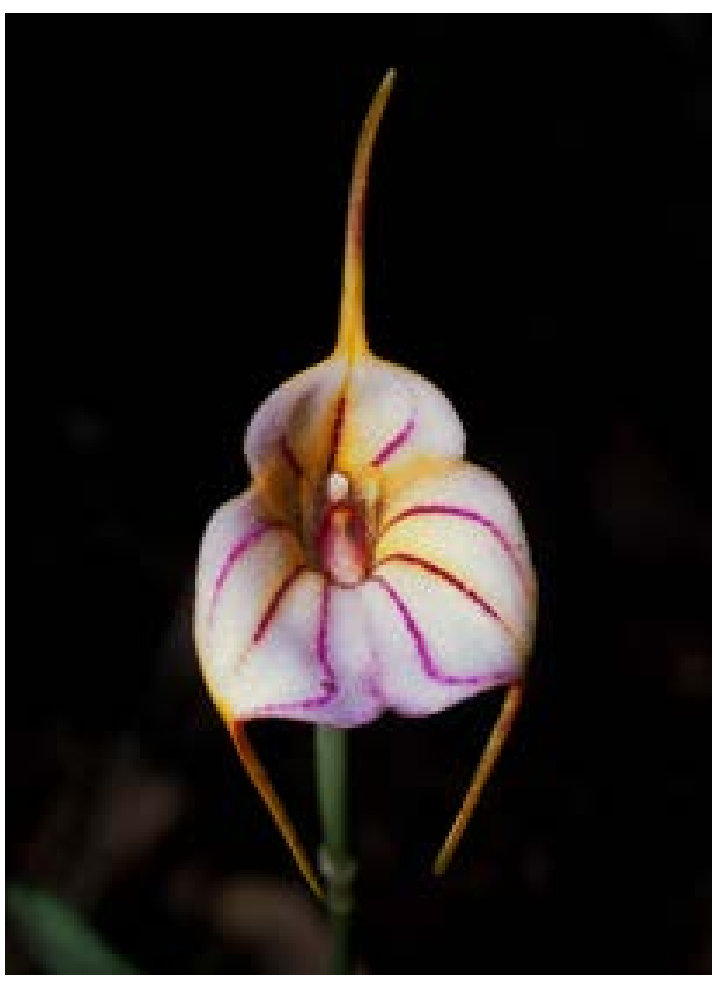

FiguRE 5. Masdevallia rimarima-alba, Huasahuasi. Photo by Stig Dalström.

Cochas, $\mathrm{S} 11^{\circ} 41.008^{\prime}, \mathrm{W} 075^{\circ} 04.22^{\prime}$, alt. 2800 m. 13 Nov. 2011, S. Dalström 3508 (USM).

Distribution: Masdevallia hortilankesteriani is only reported from steep grassy and rocky slopes of the Andes near the town of Comas, in the region of Junín, where it often grows in full sun along the road.

ETYMology: Named in honor of Lankester Botanical Garden and its staff, in recognition of their support for orchid research in general and in the New World tropics in particular.

\section{Masdevallia karelii Dalström \& Ruíz-Pérez, sp. nov.}

TYPE: Peru. Puno, Sandia, along Rio Chullo in dense, mossy cloud forest, $\mathrm{S} 14^{\circ} 20.769^{\prime}, \mathrm{W} 69^{\circ} 26.836^{\prime}$, alt. ca. 2700 - 2800 m, 25 Nov. 2010, S. Dalström 3533 (holotype, USM). Figs. 6-8.

Diagnosis: Masdevallia karelii is most similar to species such as Masdevallia dudleyii Luer, M. nunezii Luer \& Dalström, M. juan-albertoi Luer \& M.Arias, and M. terborchii Luer, all occurring in the highlands of central Peru, but our new species is distinguished from them all by the rich magenta sepaline pubescence.

Epiphytic herb. Plant medium to tall in size, caespitose, root-thickness medium for the genus. Ramicauls stout and erect, blackish in the wild, (presumably from a benign fungus) $3.5-3.8 \mathrm{~cm}$ long, basally enclosed by 3 to 4 tubular sheaths. Leaf erect, coriaceous, petiolate, blade basally conduplicate and cuneate, elliptic to ovate, obtuse, $10-16 \times 1.8-2.3 \mathrm{~cm}$, including the to ca. $5 \mathrm{~cm}$ long blackish-flushed petiole. Inflorescence erect, slender, single-flowered, with a to $c a .13 \mathrm{~cm}$ long peduncle; peduncular bract above the middle of the peduncle, tubular $c a .0 .9 \mathrm{~cm}$ long; floral bract tubular, to $c a .1 .3 \mathrm{~cm}$ long; pedicel ca. $2 \mathrm{~cm}$ long; ovary smooth, $c a .0 .8 \mathrm{~cm}$ long, densely covered by blackish dots in the wild. Flower campanulate, attractive; dorsal sepal basally dark yellow, then rich magenta purple, and apically white with 3 greenish veins and tail, minutely and scatteredly pubescent externally, and richly covered internally above the middle by long purple-magenta hairs, concave, cuneate, angulateobovate, connate with the lateral sepals for $c a .1 .2$ $\mathrm{cm}$, then obtuse to acute with a slender, gently curved tail, $c a .5 .5 \times 1.5 \mathrm{~cm}$, including the $3.5 \mathrm{~cm}$ long tail; lateral sepals similar in color and texture, connate for $c a .1 .4 \mathrm{~cm}$, angulate-ovate, acute with a slender, recurved apical tail, $c a .5 .0 \times 2.7 \mathrm{~cm}$, including the ca. $3 \mathrm{~cm}$ long tail; petals white, shortly unguiculate, cartilaginous, oblong, truncate and obliquely bilobed apically, and with a large, incurved basal lobe, or tooth, continuing as a fleshy keel along the lower edge, diminishing towards the apex, $c a .6 \times 2 \mathrm{~mm}$; lip whitish with magenta flush and specks, and a brownish apex, hinged on the column foot, with a basal swelling, the hypochile cordate to truncate, ovate to pandurate, the epichile with down-folded edges, acute, dorsally shallowly canaliculate between swollen longitudinal ridges, ca. $5.0 \times 2.7 \mathrm{~mm}$; column white with brownpurple ventral stripes, semiterete, straight, $c a .4 .5 \mathrm{~mm}$ long, with an equally long, curved foot; anther cap white, campanulate; pollinia not seen.

Distribution: Masdevallia karelii is only reported from a limited area near Sandia, Puno, Peru, where it grows epiphytically on mossy trunks and branches, commonly near and sometimes on the ground among mossy debris, at $2600-2800 \mathrm{~m}$. 

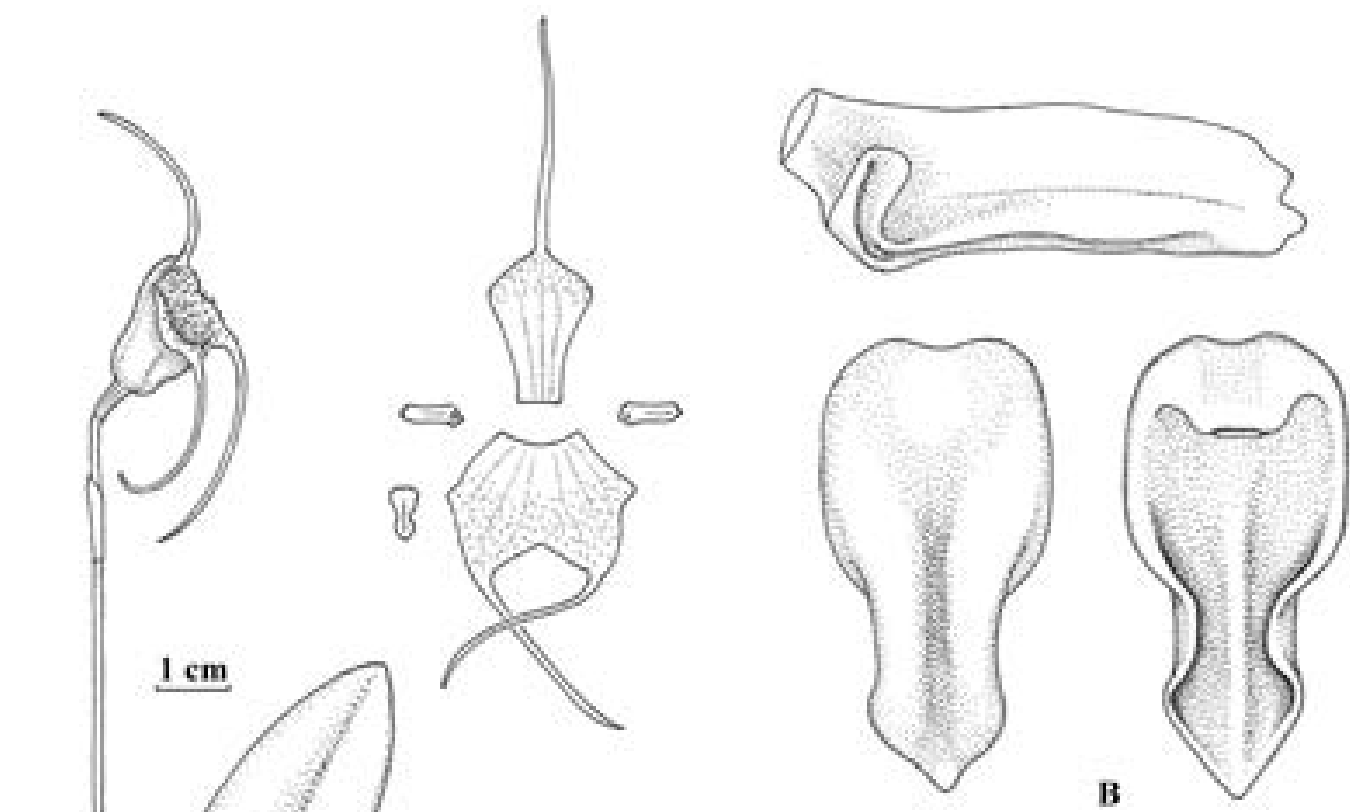

B

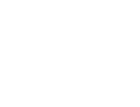

$1 \mathrm{~mm}$
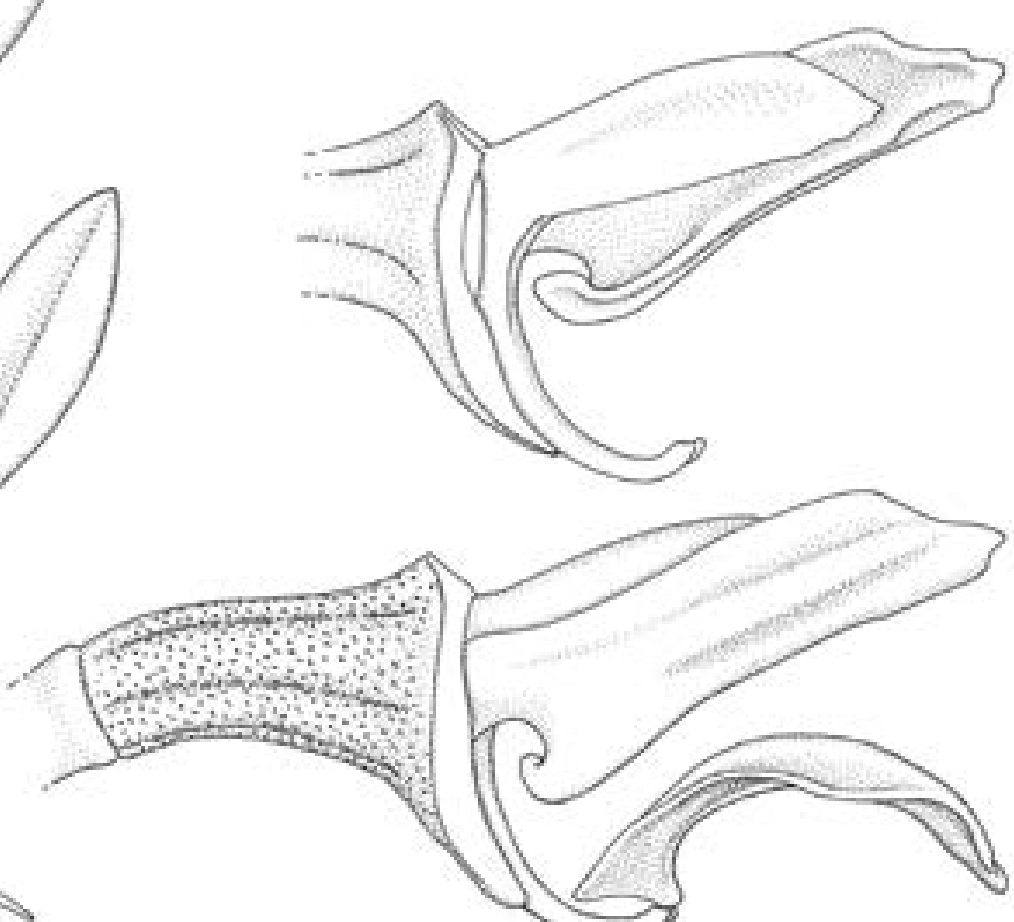

FiguRE 6. Masdevallia karelii. A — Plant habit with a dissected flower. B — Column, lip and petal views. Drawn from the holotype by Stig Dalström. 


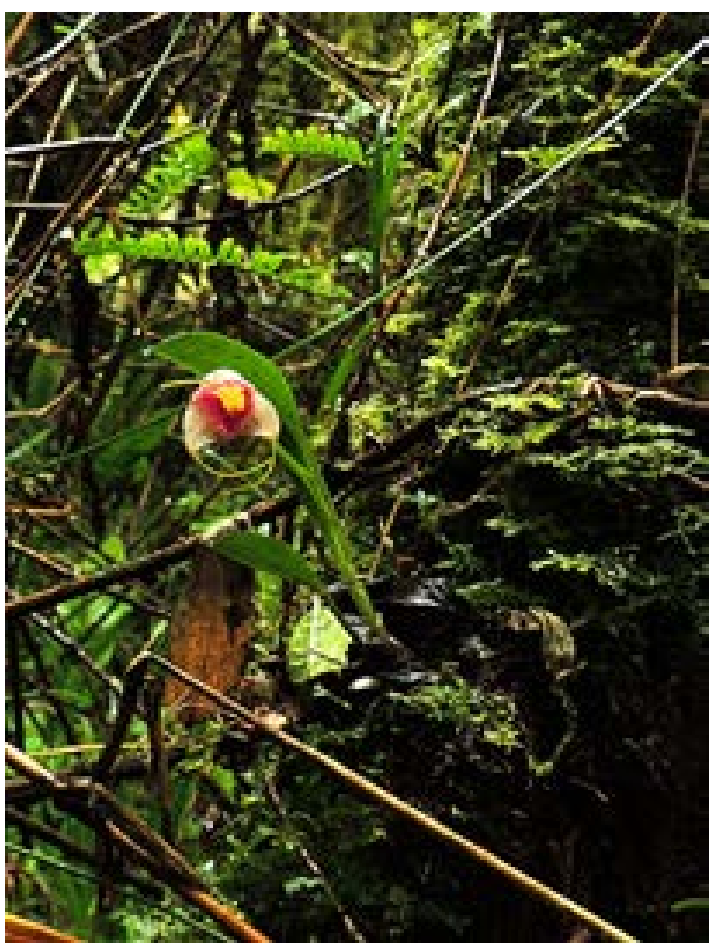

FIGURE 7. Masdevallia karelii in natural habitat (S. Dalström 3533). Photo by Karel Deburghgraeve.

Eponymy: Named in honor of Karel Deburghgraeve who participated in the discovery of this colorful species.

Masdevallia rugosilabia Dalström \& Ruíz-Pérez, sp. nov.

TYPE: Peru. Huancavelica, Salcabamba, Tayacaja, Huanca, alt. 2000 m, 8 June 2011, field-collected and flowered in cultivation by Perúflora 7 Dec. 2011, S. Dalström 3491 (holotype, USM). Figs. 9, 10.

Diagnosis: Masdevallia rugosilabia is distinguished from all other species in the genus by the combination of a tall, slender, distantly successive- or bi-flowered, terete peduncle bearing carnose, nodding flowers with a concave and rugose epichile of the lip.

Epiphytic herb. Plant slender but tall for the genus, caespitose, root-thickness medium sized. Ramicauls erect $9.0-9.5 \mathrm{~cm}$ long, enclosed basally by 3 to 4 tubular sheaths. Leaf erect, coriaceous, slender, petiolate, the blade basally conduplicate and cuneate, ovate to elliptic, acute to obtuse, $c a .15 .0 \times 2.2 \mathrm{~cm}$, including the 3.0

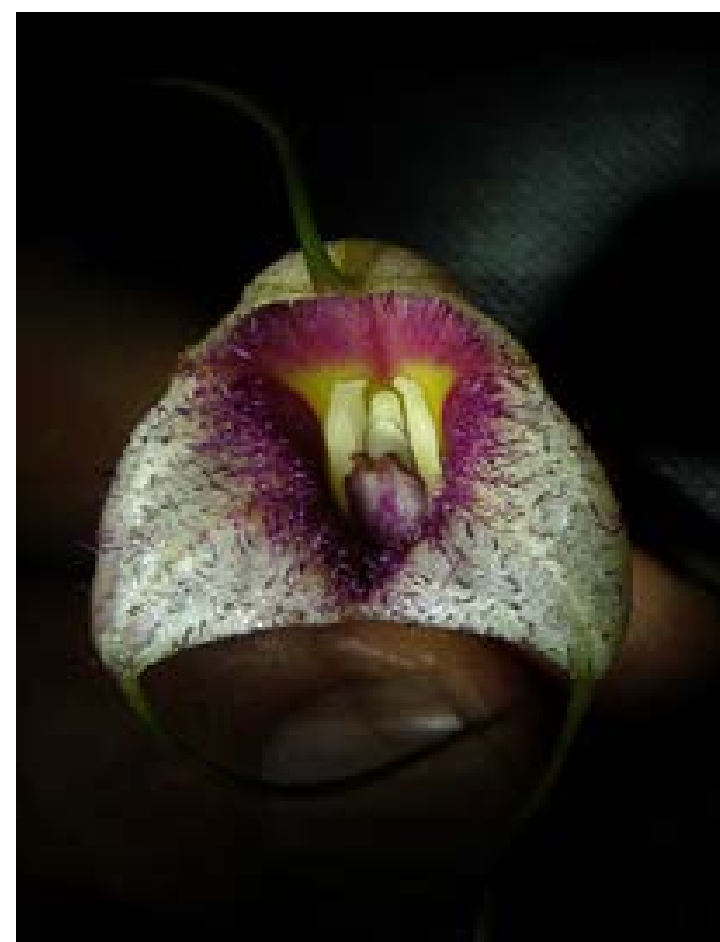

FiguRE 8. Masdevallia karelii flower (S. Dalström 3533). Photo by Stig Dalström.

$\mathrm{cm}$ long petiole. Inflorescence dark purple, erect and slightly curved, successive flowered and producing (at least) 2 nodding flowers, rather thin, with a to $c a$. $16 \mathrm{~cm}$ long peduncle and a to $c a .4 \mathrm{~cm}$ long rachis; peduncular bracts 3, below the middle, ca. $5-10 \mathrm{~mm}$ long; floral bracts tubular, ca. $1.5 \mathrm{~cm}$ long; peduncle ca. $1.6-2.0 \mathrm{~cm}$ long; ovary ca. $0.4 \mathrm{~cm}$ long, weakly carinate. Flower nodding, campanulate; dorsal sepal dark brownish purple externally, dark yellowish brown covered by darker spots internally and with a dull, dark yellowish tail, slightly concave, glabrous externally and verrucose to rugose internally, connate with the lateral sepals for $c a$. 6-7 mm, oblong and weakly angulateovate, with a fleshy acuminate sepaline tail, $c a .20$ $\times$ 4-5 mm, including the $c a .10 \mathrm{~mm}$ long tail; lateral sepals similar in color and texture, connate for $c a .10$ $\mathrm{mm}$, angulate-ovate, with a fleshy, slightly curved, short sepaline tail, ca. $15 \times 10 \mathrm{~mm}$, including the $5 \mathrm{~mm}$ long tail; petals white, thickly cartilaginous, truncate oblong, apically weakly constricted, then truncate and weakly trilobed, with a low, fleshy ridge emerging near the base and diminishing near the middle, and with an additional 


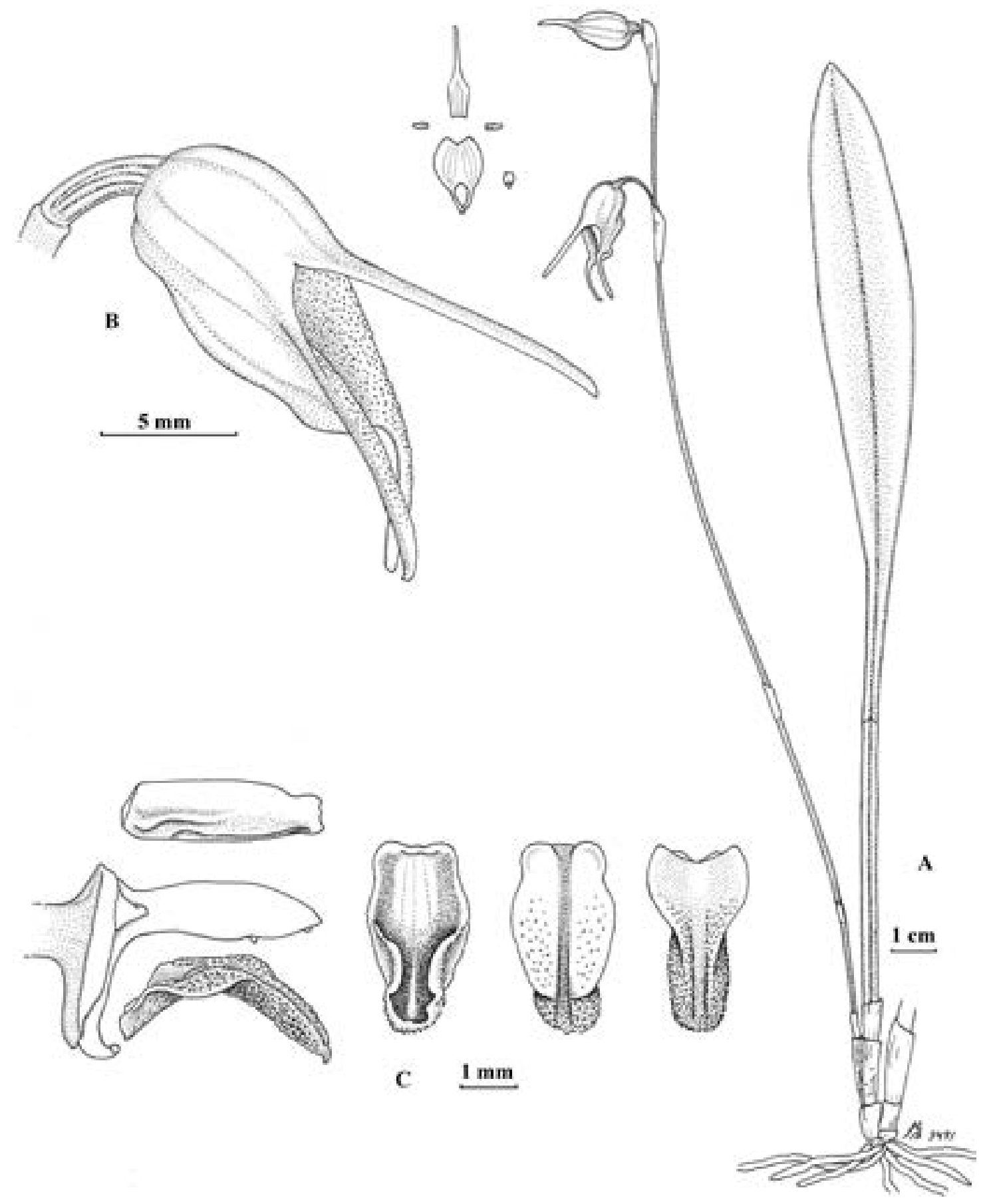

FIgURE 9. Masdevallia rugosilabia. A — Plant habit with a dissected flower. B — Column, lip and petal views. Drawn from the holotype by Stig Dalström. 


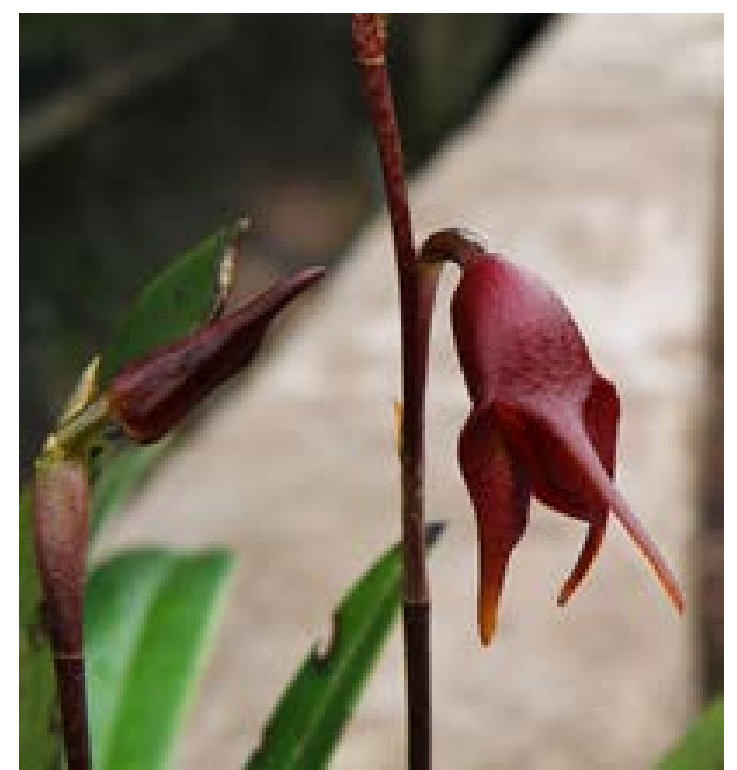

FIGURE 10. Masdevallia rugosilabia flower (S. Dalström 3491). Photo by Stig Dalström.

fleshy ridge along the lower edge, emerging from near the middle up to the apex, $c a .3 .5 \times 1.2 \mathrm{~mm}$; lip pale purple, hinged on the column foot, with a basal swelling, truncate to cordate, the hypochile flattened ovate and weakly rugose, the epichile down-folded and convex from above, rounded, rugose, dorsally canaliculate from near the base to the apex, $c a .3 .5 \times 2.0 \mathrm{~mm}$; column white, semiterete straight, $c a .4 \mathrm{~mm}$ long, with an equally long, curved foot; anther cap white, campanulate; pollinia 2, flattened pyriform.
Distribution: Known only from the type locality in central Peru.

Eтymology: The name refers to the rugose lip of the flower.

AcKNowledgement. The authors thank the staff at the Instituto Recursos Naturales (INRENA), and Betty Millán at the Universidad de San Marcos, Museo de Historia Natural, Lima, for aiding in providing the necessary collecting permits. We also thank Wesley Higgins for commenting on the manuscript, Steve Beckendorf, Guido and Karel Deburghgraeve for stimulating company in the field, and Manolo Arias together with his staff and family in Lima for gracious logistic support.

\section{LiTERATURE CITED}

Abele, C., B. Rudolph, J. Thiede \& J. G. Rohwer. 2005. Phylogeny of the genus Masdevallia Ruíz \& Pav., based on morphological an molecular data. Proceedings of the $18^{\text {th }}$ World Orchid Conference, Dijon, France, 111-115.

Luer, C. A. 1986. Icones Pleurothallidinarum 2, Systematics of Masdevallia (Orchidaceae). Monographs in systematic botany from the Missouri Botanical Garden, vol. 16.

Luer, C. A. 2006. Icones Pleurothallidinarum 28, A reconsideration of Masdevallia, Systematics of Specklinia and vegetatively similar taxa (Orchidaceae). Monographs in systematic botany from the Missouri Botanical Garden, vol. 105.

Pridgeon, A. M. \& M. W. Chase. 2001. A phylogenetic reclassification of Pleurothallidinae. Lindleyana 16(4): 235-271. 